\title{
DISFEMISME DAN TERJEMAHANNYA PADA TEKS BERITA BBC ONLINE
}

\author{
Hanifa Pascarina \\ pascarina@rocketmail.com \\ Universitas Jenderal Soedirman Purwokerto
}

\begin{abstract}
This research was aimed at identifying the uses of disfemism on BBC Online news texts at the level of grammatical units and describing their backgrounds as well as analyzing their forms and qualities of translations, particularly from the aspect of acceptability in Indonesian language. The method used for analysis was content analysis with disfemism on BBC Online news texts as the object of analysis. The data were in the forms of linguistic units of the news texts containing disfemism. The data were then analyzed by using referential comparison technique with semantic and translation approach to understand the meanings of disfemism and pragmatic comparison for analyzing the backgrounds. The results show that the grammatical units of disfemism on BBC Online news texts were at the levels words, phrases, and clauses. In addition, no significant change of form was found in the translations.There were found 10 different reasons underlying the uses of disfemism on BBC Online news texts. Meanwhile, dealing with the acceptability, most of the translations of disfemism can be counted as acceptable
\end{abstract}

Keywords: disfemism, trenslation, news, BBC Online

\section{Pendahuluan}

Sejalan dengan bahasa yang selalu mengalami perkembangan oleh masyarakat tuturnya, makna kata juga dapat mengalami perubahan. Misalnya, seperti yang diungkapkan oleh Chaer (2009, 131) bahwa dalam bahasa Indonesia ada kata 'seni' yang pada mulanya selalu dihubungkan dengan air seni atau kencing. Namun, kini digunakan sepadan dengan makna kata Inggris art atau kata Belanda kuns, yakni untuk memaknai karya ciptaan yang bernilai halus dan sering digunakan dalam frasa 'seni lukis', 'seni musik', dan lain sebagainya. Menurut Chaer (2009, 131-139) perubahan tersebut terjadi karena perkembangan dalam ilmu dan teknologi, perkembangan sosial dan budaya, perbedaan bidang pemakaian, adanya asosiasi, pertukaran tanggapan indera, perbedaan tanggapan, adanya penyingkatan, proses gramatikal, dan pengembangan istilah. Selanjutnya, Chaer (2009, 140-144) juga menyebutkan enam jenis perubahan makna yaitu: menyempit, meluas, perubahan total, penghalusan (eufemia/eufemisme), dan pengasaran (disfemia/disfemisme).

Disfemisme adalah upaya untuk mengganti kata atau ungkapan yang halus dengan kata atau ungkapan yang bermakna kasar (Chaer 2010, 88). Penggunaan disfemisme sering ditemukan dalam kolom-kolom berita maupun opini baik di surat kabar, televisi, maupun situs-situs berita online. Selain itu, mantan presiden Indonesia yakni presiden BJ Habibie pada pidatonya dalam pembukaan Kongres Bahasa Indonesia 1998 mengakui bahwa bahasa Indonesia saat ini cenderung mengarah ke bentuk pengasaran atau disfemisme (Alwi dalam Kasan 2011). Bentuk pengasaran bahasa yang berkembang terlihat dalam pemakaian disfemisme pada berita-berita di surat kabar, media online maupun di TV. Penggunaan disfemisme ini mengakibatkan suatu 
ujaran atau ungkapan bernilai rasa kasar dan jika digunakan dalam berita dianggap akan menarik minat pembaca.

BBC merupakan salah satu lembaga penyiaran (broadcasting) yang tertua dan terbesar di dunia. Media ini juga telah menyediakan web portal yang dapat diakses dengan mudah. Tujuan media ini adalah untuk memberikan informasi, mendidik dan menghibur pengaksesnya karena di dalamnya ditemukan berbagai informasi dari segala penjuru dunia. Selain itu, BBC juga menyediakan layanan informasi dalam berbagai bahasa termasuk dalam bahasa Indonesia sehingga informasinya bisa dibaca oleh siapapun tanpa ada kendala bahasa. Seperti media massa pada umumnya, BBC Online menggunakan bahasa yang tidak selalu apa adanya. Digunakan juga bahasa yang diperkasar. Misalnya, The Khadrs have been called Canada's first family of terror (Keluarga Khadrs disebut sebagai 'keluarga teror pertama' Kanada) (BBC Online, 8 /5/2015). Penggunaan frasa first family of terror atau bila diterjemahkan kedalam bahasa Indonesia menjadi 'keluarga teror pertama' merupakan ungkapan yang tidak pantas. Frasa ini sengaja dituliskan pada kolom berita dengan tujuan untuk memberikan gambaran negatif pada keluarga Khadrs yang diberitakan.

Disfemisme dapat muncul dalam bentuk satuan gramatikal yang berbeda-beda. Mengetahui satuan gramatikal disfemisme menjadi penting untuk membantu pembaca memahami teks yang dibaca tersebut. Sementara itu, dengan mengetahui latar belakang penggunaan disfemisme akan membantu pembaca menerapkan, menggunakan, atau menganalisis penggunaan disfemisme tersebut sesuai dengan konteks yang tepat.

Penelitian sebelumnya mengenai disfemisme telah dilakukan, namun belum mengkaji penerjemahan atau menghubungkan dengan ilmu penerjemahan. Seperti yang telah dilakukan oleh Auriga Maulana pada tahun 2011 dalam penelitiannya yang hanya fokus pada bentuk-bentuk disfemisme dalam tataran kata dan frasa pada kolom berita utama surat kabar Joglo Semar. Penelitian lain juga dilakukan oleh Heti Kurniawati yang membandingkan disfemisme dan eufemisme yang terdapat pada majalah online berbahasa Jerman, Spiegel. Melihat masih sedikitnya penelitian sebelumnya mengenai disfemisme yang dikaitkan dengan penerjemahan, penelitian ini mencoba untuk menganalisis bentuk satuan gramatikal penggunaan disfemisme dan terjemahan pada teks berita $\mathrm{BBC}$ Online.

Dalam bidang penerjemahan, seorang penerjemah tidak hanya bertugas menerjemahkan bahasa sumber ke bahasa sasaran saja, tetapi juga memperhatikan aspek-aspek linguistik yang mengikat teks bahasa sumber tersebut agar dapat menghasilkan teks terjemahan yang akurat dan berterima. Aspek linguistik yang dimaksud dapat meliputi ranah pragmatik, sosiolinguistik, semantik, dan lainnya. Penggunaan disfemisme merupakan salah satu kajian di bidang semantik dan masih mendapat sedikit perhatian dari kalangan akademisi untuk mengkaji disfemisme dan terjemahannya. Analisis terjemahan disfemisme dirasa perlu karena selain dapat memperkaya ilmu dalam bidang linguistik penerjemahan, juga dapat memberikan beberapa saran pengambilan keputusan bagi para penerjemah ketika menghadapi teksteks berita internasional yang mengandung disfemisme, apakah ungkapan disfemisme tersebut diterjemahkan menjadi disfemisme atau malah diperhalus dengan menggunakan ungkapan yang pantas. Pengambilan keputusan oleh penerjemah ini juga dapat mempengaruhi ideologi mereka apakah 
penerjemah tersebut berorientasi ke bahasa sumber ataukah bahasa sasaran.

Dengan latar belakang masalah yang telah dipaparkan diatas dan latar belakang media BBC yang berskala internasional, kiranya perlu untuk mengkaji disfemisme yang ditemukan pada berita-berita BBC dan terjemahannya dalam bahasa Indonesia yang terdapat pada situs BBC versi bahasa Indonesia. Penelitian ini membahas penggunaan disfemisme yang ditemukan pada teks berita BBC Online dan terjemahannya dalam bahasa Indonesia yang dapat ditemukan pada alamat internet: www.bbc.co.uk/indonesia.

Penelitian ini bertujuan untuk: (1) mengidentifikasi bentuk satuan gramatikal penggunaan disfemisme yang ditemukan pada teks berita BBC Online; (2) mendeskripsikan latar belakang penggunaan disfemisme yang ditemukan pada teks berita BBC Online; dan (3) mendeskripsikan bentuk gramatikal terjemahan bahasa Indonesia penggunaan disfemisme dan penilaian kualitas terjemahan teks berita BBC Online dalam hal keberterimaan.

\section{KAJIAN Pustaka}

Disfemisme merupakan kebalikan dari eufemisme (penghalusan) yaitu pengasaran. Disfemisme dapat meliputi makian, memberi julukan kepada seseorang atau sesuatu, dan memberi komentar negatif langsung kepada seseorang atau sesuatu untuk menghina dan menyakiti mereka. Secara teknis, disfemisme menurut Allan \& Burridge (2006, 31), merupakan a word or phrase with connotations that are offensive either about the denotatum and/ or to people addressed or overhearing the utterance.

Disfemisme dapat muncul dalam bentuk satuan gramatikal yang berbeda-beda. Disfemisme dapat berupa kata, misal 'menjebloskan' untuk mengganti kata 'memasukan' seperti dalam kalimat 'Polisi menjebloskan terpidana korupsi itu ke dalam sel'. Disfemisme juga dapat berupa frasa, seperti 'kurungan penjara' seperti dalam kalimat 'Pria kelahiran Kanada ini, menyetujui kesepakatan untuk menjalani kurungan penjara selama delapan tahun'. Disfemisme dapat berupa klausa, misal 'dijatuhkan di tengah jalan' dalam kalimat 'Jangan sampai SBY dijatuhkan di tengah jalan'.

Selain bentuk satuan gramatikal disfemisme yang berbeda-beda, latar belakang penggunaannya pun berbedabeda. Mengetahui latar belakang penggunaan disfemisme tersebut akan membantu pembaca menerapkannya dalam berkomunikasi, sesuai dengan konteks yang tepat. Menurut Kurniawati (2011, 60) dalam hasil penelitiannya, latar belakang penggunaan disfemisme dibagi menjadi 10, yaitu: (1) menyatakan hal yang tabu, tidak senonoh, asusila; (2) menunjukkan rasa tidak suka atau tidak setuju terhadap seseorang atau sesuatu; (3) penggambaran yang negatif tentang seseorang atau sesuatu; (4) mengungkapkan kemarahan atau kejengkelan; (5) mengumpat atau memaki; (6) menunjukkan rasa tidak hormat atau merendahkan seseorang; (7) mengolok-olok, mencela, atau menghina; (8) melebih-lebihkan sesuatu; (9) menghujat atau mengkritik; dan (10) menunjukkan sesuatu hal yang bernilai rendah.

Penerjemahan adalah proses mentransformasi teks dari bahasa sumber ke bahasa sasaran dengan cara menyampaikan pesan secara akurat dan berterima dengan budaya bahasa sasaran. Hal ini seperti yang diungkapkan Nababan (2003, 18-23) bahwa istilah translation atau 'penerjemahan' mengacu pada pengalihan pesan tertulis dan lisan. Nababan juga menegaskan bahwa selain memperhatikan kesetiaan makna antara bahasa sumber (BSu) dan bahasa sasaran (BSa), penting bagi penerjemah untuk memperhatikan 
gaya bahasa terjemahan dan tingkat kemampuan pembaca suatu karya terjemahan. Dengan memperhatikan ketiga hal tersebut maka diharapkan proses penerjemahan bisa menghasilkan karya terjemahan berkualitas yang bisa diterima oleh pembaca. Memperoleh terjemahan yang berkualitas juga perlu diperhatikan kesepadanan dalam mengatur, menggolongkan, menyamakan gaya antara teks bahasa sumber dengan bahasa sasaran dan lain-lain. Dalam penelitian ini, penilaian kualitas terjemahan hanya dianalisis pada aspek keberterimaan pada bentuk gaya bahasa disfemisme, apakah bentuk disfemisme tersebut dalam bahasa sumber diterjemahkan juga menjadi disfemisme pada bahasa sasaran.

\section{Metode Penelitian}

Penelitian ini menggunakan metode analisis isi, yakni analisis yang digunakan untuk memahami pesan simbolik yang ada dalam dokumen, lukisan, tarian, lagu, karya sastra, dan lain-lain yang berupa data tidak terstruktur (Zuchdi 1993, 6). Langkahlangkah analisis isi mencakup empat tahapan. Tahapan pertama adalah pengadaan data yang meliputi penentuan satuan (unit), penentuan sampel, dan pencatatan. Tahapan selanjutnya adalah pengurangan atau reduksi data yang tidak diperlukan, analisis data yang dilakukan secara kualitatif, dan inferensi atau penarikan kesimpulan (Zuchdi 1993, 28).

Objek analisis penelitian ini adalah teks berita BBC Online, sedangkan data penelitian ini berupa satuan lingual dalam teks berita BBC Online yang mengandung disfemisme. Sementara itu, konteks data penelitian ini berupa kalimat bila datanya berupa kata, frasa, dan klausa. Konteks data menjadi sangat penting peranannya untuk mengklasifikasi makna disfemisme dan terjemahannya, serta untuk mengungkapkan alasan penggunaannnya. Rubrik yang digunakan sebagai sumber data adalah rubrik berita. Berita yang dipilih sebagai sumber data adalah beritaberita yang ditampilkan pada edisi tanggal 6 hingga 11 Mei 2015.

Teknik pengumpulan data yang digunakan dalam penelitian ini adalah teknik simak dan catat. Simak yang dimaksud dalam penelitian ini berarti membaca dengan seksama berita dalam BBC Online untuk menentukan bentuk satuan gramatikal disfemisme serta latar belakang penggunaannya. Data dikumpulkan beserta konteksnya. Di dalam kegiatan pembacaan dilakukan kegiatan pencatatan untuk mendokumentasikan data yang diperoleh.

Teknik analisis data yang digunakan adalah teknik padan. Teknik padan merupakan teknik analisis yang alat penentunya berada di luar bahasa dan tidak menjadi bagian dari bahasa itu sendiri (Sudaryanto 2001). Selanjutnya teknik padan yang digunakan adalah teknik padan referensial untuk mengetahui satuan gramatikal disfemisme dan terjemahannya. Teknik padan referensial dengan pendekatan semantik dan penerjemahan digunakan untuk mengetahui makna disfemisme. Sementara itu, untuk menganalisis latar belakang disfemisme digunakan analisis padan pragmatik.

\section{DISFEMISME PADA TEKS BERITA BBC ONLINE}

\section{Satuan Gramatikal Disfemisme}

Berdasarkan bentuknya, satuan gramatikal disfemisme pada teks berita BBC Online dapat dibagi menjadi satuan gramatikal kata, frasa, dan kalimat.

Kata

Disfemisme dalam bentuk kata ditunjukkan pada konteks berita berikut.

$\mathrm{BSu}$ : Lubitz is suspected of deliberately crashing the Airbus 320, killing all 150 people on board. 
BSa : Lubitz diduga secara sengaja menabrakkan Airbus 320, ketika pilot berada di luar kokpit, menewaskan 150 orang di dalam pesawat.

Kata killing (menewaskan) merupakan kata kerja. Dalam konteks berita diatas kata killing telah mengalami proses gerund, yakni objek langsung dari kata depan of dari kata kerja suspected of (the direct object of preposition'of'). Berita tersebut mengenai korban kecelakaan pesawat Germanwings. Kata killing termasuk disfemisme karena memiliki kesan yang buruk. Dalam konteks kalimat diatas, killing (menewaskan) lebih halus bila menggunakan take life dan terjemahannya menjadi 'memakan korban'.

Frasa

Disfemisme yang berupa frasa, seperti pada data berikut.

$\mathrm{BSu}$ : Room number 207 at one of the city's family courts with its blue upholstered chairs, the smell of anxiety, of depleted people, of lawyers with dog-eared case files, the attendant's loud voice calling out case numbers, still haunt me.

BSa : Bayangan ruangan 207 di salah satu pengadilan keluarga di Kota Delhi masih menghantui saya. Di sanalah saya menghabiskan berjam-jam dengan penuh kecemasan seraya memandangi orang-orang yang juga gelisah dan pengacara-pengacara yang membawa tumpukan map lusuh.

Kelompok kata dog-eared case files atau 'tumpukan map lusuh' merupakan frasa, karena tidak memiliki kata kerja finit dan fungsi predikatif. Kepala dari kelompok kata di atas adalah kata case files. Kata dogeared yang merupakan kata sifat hanya merupakan atribut bagi kata case files yang merupakan kata benda. Frasa dog-eared case files atau 'tumpukan map lusuh' dalam kalimat di'atas merupakan bentuk disfemisme karena memberi kesan buruk pada sesuatu yaitu case file.

\section{Klausa}

Disfemisme yang berupa frasa, seperti pada contoh berikut.

$\mathrm{BSu}$ : The first in my parents' families to announce to the world that my marriage was on the rocks, I was filled with trepidation at the thought of divorce.

BSa : Saya merupakan orang pertama di keluarga besar yang harus mengakui bahwa pernikahan saya hancur. Saya gemetar ketakutan membayangkan kata cerai.

My marriage was on the rocks (pernikahan saya hancur) memiliki subjek (S) My marriage dan predikat (P) was on the rocks. Karena memiliki unsur predikatif, maka My marriage was on the rocks merupakan kalimat. Dalam konteks berita diatas, my marriage was on the rocks merujuk pada disfemisme yaitu menggambarkan rasa marah atau jengkel karena perceraiannya.

\section{Latar Belakang Penggunaan Disfemisme \\ Latar belakang penggunaan disfemisme berbeda-beda. Berikut ini latar belakang penggunaan disfemisme pada teks berita BBC Online.}

\section{Penggambaran sesuatu secara negatif}

Pertama, disfemisme ditafsirkan untuk menggambarkan nilai negatif akan sesuatu, seperti yang ada pada data berikut ini:

In April, the justice department issued a report detailing widespread abuse at the police department in Albuquerque, New Mexico.

Berita tersebut menjelaskan bahwa Departemen Kehakiman Amerika Serikat telah merilis laporan mengenai adanya pelecehan di departemen kepolisian di Albuquerque, New Mexico. Frasa widespread abuse (pelecehan) merupakan disfemisme karena menunjukkan suatu hal/kejadian yang negatif. Hal negatif tersebut, sesuai dengan konteks berita, merupakan kejadian yang telah terjadi di departemen kepolisian yaitu adanya pelecehan semacam kekerasan pihak 
kepolisian saat memeriksa para tersangka atau tahanan.

Penggambaran seseorang secara nengatif

Kedua, disfemisme ditafsirkan dalam penggambaran yang negatif mengenai seseorang, seperti yang ditunjukkan oleh data berikut:

We are disappointed with today's decision, and regret that a convicted terrorist has been allowed back into Canadian society without having served his full sentence.

Frasa a convicted terrorist menunjukkan penggambaran negatif mengenai seseorang yaitu teroris itu sendiri. Orang tersebut sudah disebut sebagai teroris dan menjadi seorang terpidana. Konteks berita diatas menjelaskan bahwa pihak korban kecewa terhadap putusan hakim untuk membebaskan terpidana teroris tanpa dijatuhi hukuman penuh.

Penggambaran sekelompok orang
secara negatif

Ketiga, disfemisme digunakan dalam penggambaran negatif terhadap sekelompok orang, seperti pada contoh berikut:

The young men in fast cars have become such a conspicuous group that they even have their own nickname.

Konteks berita tersebut menjelaskan ciri-ciri kelompok penipu yang beraksi di internet yang sedang mewabah di Ghana. Mereka terdiri dari laki-laki muda, mengendarai mobil dengan kecepatan tinggi, memiliki julukan khusus untuk diri mereka, sehingga tampilan mereka yang sedemikian rupa sangat mencolok. Sesuai dengan konteks tersebut, frasa $a$ conspicuous group termasuk disfemisme yang menggambarkan keburukan/sifat negatif terhadap sekelompok orang yaitu kelompok lakilaki yang menjadi penipu di internet.
Mengungkapkan kemarahan atau kejengkelan

Keempat, disfemisme ditafsirkan untuk mengungkapkan kemarahan atau kejengkelan, seperti yang ditunjukkan oleh contoh berikut:

I can't speculate on what was happening inside his head.

Konteks berita tersebut menjelaskan tanggapan mengenai Pilot pesawat Germanwings yang sengaja menabrakkan pesawatnya di pegunungan. Klausa what was happening inside his head menunjukkan disfemisme yang merupakan rasa kemarahan atau kejengkelan mengenai tindakan pilot.

Menunjukkan rasa tidak hormat atau merendahkan seseorang

Kelima, disfemisme ditafsirkan untuk menunjukkan rasa tidak hormat atau merendahkan, seperti yang ada pada data berikut:

But the new investigation would be similar to the one that was done in Ferguson, Missouri, following the shooting of Michael Brown, an unarmed black teenager, by a white police officer in August.

Frasa an unarmed black teenager, by a white police officer merupakan disfemisme yang menunjukkan rasa tidak hormat atau merendahkan seseorang. Frasa tersebut merujuk pada penyebutan pemuda negro dengan sebutan black teenager, serta penyebutan white police officer (polisi kulit putih), yang mana hal tersebut merujuk pada rasisme. Hal yang berkaitan dengan masalah rasial sangat sensitif, termasuk dalam menyebutkan warna kulit, karena akan merendahkan ras tersebut. Konteks berita diatas yaitu mengenai penyelidikan Ferguson Missouri pada kasus penembakan terhadap Michael Brown, seorang pemuda Afrika yang tak bersenjata, oleh seorang aparat kepolisian bukan asli Afrika. 


\section{Menunjukkan sesuatu yang bernilai rendah}

Keenam, disfemisme ditafsirkan untuk menunjukkan sesuatu hal yang bernilai rendah, seperti yang ada pada data berikut ini:

Canadian-born, he agreed a plea deal to leave Guantanamo and serve the majority of his eight-year sentence there.

Konteks situasi berita tersebut menjelaskan bahwa setelah tersangka diberi keringanan hukuman dan keluar dari penjara Guantanamo, dia harus mengabdi kepada masyarakat. Penggunaan frasa serve the majority (melayani masyarakat) dalam konteks diatas semakin menunjukkan bahwa hukuman yang diterima seseorang yang baru saja keluar dari penjara karena adanya keringanan hukuman merupakan sesuatu yang bernilai rendah.

\section{Mencela atau menghina}

Ketujuh, disfemisme ditafsirkan untuk mencela atau menghina, misal yang ada pada contoh berikut ini:

The Khadrs have been called Canada's 'first family of terror'

First family terror (keluarga teror pertama) dalam konteks di atas yang digunakan untuk menyebut keluarga Khadrs merupakan suatu bentuk celaan atau hinaan. Keluarga Khadrs yang diberitakan disebut sebagai keluarga teror pertama di Kanada karena seluruh anggota keluarga tersebut terlibat kegiatan aksi terorisme.

\section{Melebih-lebihkan sesuatu}

Kedelapan, disfemisme ditafsirkan untuk melebih-lebihkan sesuatu, seperti yang ditemukan pada data berikut ini:

\section{Mayor Stephanie Rawlings-Blake requested the inquiry after Freddie Gray suffered fatal injuries when arrested}

Penggunaan frasa fatal injuries (luka parah) dalam kalimat di atas menunjukkan bahwa penulis ingin mengungkapkan betapa parahnya luka
Freddie Gray yang didapatnya saat menjadi tahanan kepolisian. Konteks situasi berita tersebut menceritakan bahwa Freddie Gray meninggal dengan banyak luka di tubuhnya selama dia ditahan. Oleh karena itu, penggunaan frasa fatal injuries dirasa lebih memiliki kesan mematikan hingga membuat seseorang kehilangan nyawa.

\section{Mengkritik}

Kesembilan, disfemisme ditafsirkan untuk mengkritik. Hal ini dapat ditemukan pada contoh nomor 17 berikut ini:

\section{She said the community and the police had a fractured relationship.}

Frasa a fractured relationship (hubungan yang retak) pada kalimat di atas termasuk frasa disfemistis. Sesuai dengan konteks berita yang melatarbelakangi kalimat diatas, frasa tersebut digunakan untuk mengkritik hubungan masyarakat dan pihak polisi yang retak atau tidak harmonis lagi. Berita tersebut berisi pernyataan Walikota Stephanie Rawlings-Blake yang meminta penyelidikan mendalam setelah kematian seorang tahanan bernama Freddie Gray. Dia diduga mengalami kekerasan oleh pihak kepolisian. Ibu walikota ini mengatakan bahwa peristiwa tersebut mencerminkan hubungan antara masyarakat dan kepolisian tidak dalam kondisi baik.

\section{Menunjukkan rasa tidak suka terhadap sesorang}

Kesepuluh, disfemisme ditafsirkan untuk menunjukkan rasa tidak suka terhadap seseorang, seperti yang terdapat pada data berikut ini:

From several divorce lawyers, I came to understand that a tacit understanding exists between junior staff of some family courts, marriage portal officials and unscrupulous lawyers who exchange information on possible candidates for a second marriage-all for a fee.

Frasa unscrupulous lawyers disini bermakna pengacara yang tak 
bermoral. Konteks situasi berita tersebut menceritakan kekesalan seorang wanita yang sedang menghadapi sidang proses perceraian, terhadap oknum pengacara yang memberikan informasi pribadinya kepada biro perjodohan. Oknum pengacara tersebut sengaja saling bertukar informasi dengan biro perjodohan mengenai orang-orang yang mereka pikir ingin menikah lagi setelah baru bercerai karena diberikan upah. Dengan penggunaan disfemisme di atas, wanita tersebut hendak menyampaikan ketidaksukaannya terhadap tindakan para pengacara tersebut.

\section{TerJemahan Disfemisme TeKS BERITA BBC ONLINE \\ Perubahan Bentuk Satuan \\ Gramatikal Terjemahan \\ Disfemisme}

Pada analisis perubahan bentuk satuan gramatikal terjemahan disfemisme teks berita BBC Online, dari 32 data, ditemukan ada 5 data yang mengalami perubahan satuan bentuk gramatikalnya, yakni 4 data berupa perubahan bentuk dari frasa ke kata dan 1 perubahan dari kata menjadi frasa. Dari kelima data tersebut, empat diantaranya dinilai berterima dan sisanya dinilai tidak berterima. Oleh karena itu, perubahan bentuk yang terjadi pada terjemahan disfemisme tidak berpengaruh kepada kualitas terjemahan karena perubahan terjadinya bentuk dipengaruhi oleh struktur bahasa yang berbeda antara bahasa sumber dan bahasa sasaran.

\section{Penilaian Keberterimaan Terjemahan Disfemisme}

Analisis terjemahan kata, frasa, atau klausa yang mengandung disfemisme pada penelitian ini lebih difokuskan pada penilaian kualitas terjemahan, terutama pada aspek keberterimaannya.

Aspek keberterimaan merupakan kewajaran dan kealamiahan terjemahan yang merefleksikan ketaatan pada kaidah dan budaya bahasa sasaran. Oleh karena itu, apabila dalam bahasa sumber ditemukan ungkapan disfemisme, penerjemah perlu mempertimbangkan kaidah dan budaya pada bahasa sasaran, apakah menerjemahkannya sebagai disfemisme juga atau tidak.

Kemudian, untuk menilai terjemahannya, digunakan parameter aspek keberterimaan, apakah ungkapan disfemisme tersebut berterima sebagai disfemisme juga di bahasa sasaran, kurang berterima, atau malah tidak berterima.

Penilaian

keberterimaan terjemahan disfemisme yang ada pada data penelitian ini sebagian besar dinilai berterima, yang artinya penerjemah banyak menerjemahkan disfemisme menjadi disfemisme dan berterima pada bahasa sasaran. Namun juga ditemukan adanyaterjemahan disfemisme tidak berterima. Sementara itu, tidak ditemukan data yang dinilai kurang berterima.

\section{Terjemahan Disfemisme yang Berterima}

Terjemahan disfemisme dikatakan berterima apabila terjemahan terasa natural, ungkapan yang mengandung disfemisme digunakan secara lazim dan akrab bagi pembaca sasaran. Berikut data yang termasuk dalam kategori terjemahan berterima:

BSu : $M r$ Somers, and South African teacher Pierre Korkie, were killed by al-Qaeda militants in Yemen last December.

BSa : Somers, dan guru asal Afrika Selatan Pierre Korkie, tewas oleh militan al-Qaeda di Yaman pada Desember lalu.

Data di atas menunjukkan contoh penerjemahan yang berterima. Disfemisme yang ditemukan di bahasa sumber yakni al-Qaeda militants diterjemahkan dengan teknik peminjaman (borrowing) menjadi 
'militan al-Qaeda' yang dimaknai sebagai kelompok radikal. Walaupun terjemahan merupakan kata pinjaman, hal ini tidak mempengaruhi kealamiahannya, dan bentuknya tetap sebagai disfemisme.

\section{Terjemahan Disfemisme yang Tidak Berterima}

Pada data penelitian ini, hanya ditemukan dua data terjemahan yang dinilai tidak berterima. Berikut adalah contoh terjemahan yang dinilai tidak berterima.

BSu : From several divorce lawyers, I came to understand that a tacit understanding exists between junior staff of some family courts, marriage portal officials and unscrupulous lawyers who exchange information on possible candidates for a second marriage-all for a fee.

BSa : Oleh beberapa pengacara perceraian, saya dijelaskan bahwa terdapat kesepakatan antara staf di pengadilan, pengurus biro pernikahan, dan pengacara. Mereka saling bertukar informasi mengenai orang-orang yang mereka pikir ingin menikah lagi setelah baru bercerai.

Data ini termasuk data terjemahan yang dinilai tidak berterima sebagai disfemisme. Pada BSu ditemukan frasa disfemisme unscrupulous lawyers. Seperti yang sudah dijelaskan sebelumnya, kata unscrupulous disini bermakna 'tak bermoral' menjelaskan pengacara yang disebutkan. Penerjemah menggunakan teknik reduksi (reduction) dengan menghilangkan kata unscrupulous pada frasa ini, sehingga hanya diterjemahkan menjadi 'pengacara'. Walaupun terjemahannya terasa natural dalam bahasa sasaran namun bentuk disfemismenya hilang sehingga terjemahan frasa tersebut dinilai tidak berterima sebagai disfemisme. Agar tetap berterima sebagai disfemisme dan juga terasa kealamiahan pada bahasa sasaran, mungkin frasa tersebut dapat diterjemahkan menjadi 'pengacara tak bermoral'.

\section{SIMPULAN}

Dari uraian di atas, dapat disimpulkan bahwa bentuk satuan gramatikal disfemisme pada teks berita BBC Online berupa kata, frasa, dan klausa. Disfemisme yang paling banyak muncul berupa satuan gramatikal kata. Selain itu, tidak ditemukan perubahan bentuk yang signifikan pada terjemahannya karena hanya ditemukan 5 bentuk satuan gramatikal yang berubah dari 32 data dan hal itu tidak mempengaruhi keberterimahan terjemahan disfemisme.

Latar belakang penggunaan disfemisme pada teks berita BBC Online ditafsirkan untuk beberapa alasan yang mengandung ungkapan tidak halus.

Penilaian

keberterimaan terjemahan disfemisme yang ada pada data penelitian ini sebagian besar dinilai berterima. Artinya, penerjemah banyak menerjemahkan disfemisme menjadi disfemisme dan berterima pada bahasa sasaran. Namun juga ditemukan adanya 2 data terjemahan disfemisme yang tidak berterima. Terjemahan ini tidak berterima karena penerjemah mengganti makna frasa yang termasuk disfemisme menjadi bukan disfemisme pada bahasa sasaran melalui teknik reduksi dengan tidak menerjemahkan salah satu kata. Sementara itu, tidak ditemukan adanya data yang dinilai kurang berterima.

\section{DAFtar Pustaka}

Allan \& Burridge. 2006. Forbidden Words: Taboo and The Censoring of Language. Cambridge: Cambridge University Press

Chaer, Abdul. 2009. Pengantar Semantik Bahasa Indonesia. Jakarta: Rineka Cipta

Chaer, Abdul. 2010. Bahasa Jurnalistik. Jakarta: Rineka Cipta

Kurniawati, Heti. 2011. "Eufemisme dan Disfemisme dalam Spiegel Online". Jurnal. Malang: Universitas Negeri Malang 
Maulana, Auriga. 2011. "Pemakaian Disfemisme dalam Kolom Berita Utama Surat Kabar Joglo Semar". Surakarta: Universitas Sebelas Maret

Nababan, MR. 2003. Teori Menerjemahkan Bahasa Inggris. Yogyakarta: Pustaka Pelajar
Sudaryanto. 2001. Metode Aneka Teknik Analisis Bahasa. Yogyakarta: Wacana University Press

Zuchdi, Darmiyati. 1993. Panduan Penelitian Analisis Konten. Yogyakarta: Lembaga Penelitian IKIP Yogyakarta 